\title{
Detection and quantification of classic and emerging viruses by skimmed-milk flocculation and PCR in river water from two geographical areas
}

\author{
Byron Calgua ${ }^{a}$, Tulio Fumian ${ }^{b}$, Marta Rusiñol ${ }^{a}$, Jesus Rodriguez-Manzano ${ }^{a}$, \\ Viviana A. Mbayed ${ }^{c}$, Silvia Bofill-Mas ${ }^{a}$, Marize Miagostovich ${ }^{b}$, Rosina Girones ${ }^{a, *}$ \\ ${ }^{a}$ Department of Microbiology, Faculty of Biology, University of Barcelona, Av. Diagonal 643, Barcelona 08028, Spain \\ ${ }^{b}$ Laboratory of Comparative and Environmental Virology, Oswaldo Cruz Institute, Avenida Brasil 4365, Rio de Janeiro, Brazil \\ ${ }^{c}$ Laboratory of Virology, Faculty of Pharmacy and Biochemistry, University of Buenos Aires, Junín 956, Buenos Aires, Argentina
}

\section{A R T I C L E I N F O}

\section{Article history:}

Received 24 September 2012

Received in revised form

16 February 2013

Accepted 21 February 2013

Available online $\mathrm{xxx}$

Keywords:

Emerging virus

Polyomavirus

Merkel cell polyomavirus

Klassevirus

Asfarvirus-like virus

Rotavirus

Norovirus

Adenovirus

River water

Concentration method

Viral indicator

\begin{abstract}
A B S T R A C T
Molecular techniques and virus concentration methods have shown that previously unknown viruses are shed by humans and animals, and may be transmitted by sewagecontaminated water. In the present study, 10-L river-water samples from urban areas in Barcelona, Spain and Rio Janeiro, Brazil, have been analyzed to evaluate the viral dissemination of human viruses, validating also a low-cost concentration method for virus quantification in fresh water. Three viral groups were analyzed: (i) recently reported viruses, klassevirus (KV), asfarvirus-like virus (ASFLV), and the polyomaviruses Merkel cell (MCPyV), KI (KIPyV) and WU (WUPyV); (ii) the gastroenteritis agents noroviruses (NoV) and rotaviruses (RV); and (iii) the human fecal viral indicators in water, human adenoviruses (HAdV) and JC polyomaviruses (JCPyV). Virus detection was based on nested and quantitative PCR assays. For KV and ASFLV, nested PCR assays were developed for the present study. The method applied for virus concentration in fresh water samples is a one-step procedure based on a skimmed-milk flocculation procedure described previously for seawater. Using spiked river water samples, inter- and intra-laboratory assays showed a viral recovery rate of about 50\% (20-95\%) for HAdV, JCPyV, NoV and RV with a coefficient of variation $\leq 50 \%$. HAdV and JCPyV were detected in $100 \%(12 / 12)$ of the river samples from Barcelona and Rio de Janeiro. Moreover, NoV GGII was detected in 83\% (5/6) and MCPyV in $50 \%(3 / 6)$ of the samples from Barcelona, whereas none of the other viruses tested were detected. NoV GGII was detected in $33 \%(2 / 6)$, KV in $33 \%(2 / 6)$, ASFLV in $17 \%(1 / 6)$ and MCPyV in 50\% (3/6) of the samples from Rio de Janeiro, whereas KIPyV and WUPyV were not detected. RV were only analyzed in Rio de Janeiro and resulted positive in $67 \%(4 / 6)$ of the samples. The procedure applied here to river water represents a useful, straightforward and cost-effective method that could be applied in routine water quality testing. The results of the assays expand our understanding of the global distribution of the viral pathogens studied here and their persistence in the environment.
\end{abstract}

(c) 2013 Elsevier Ltd. All rights reserved.

\footnotetext{
* Corresponding author. Tel.: +34 93402 1483; fax: +34 934039047.

E-mail address: rgirones@ub.edu (R. Girones).

0043-1354/\$ - see front matter @ 2013 Elsevier Ltd. All rights reserved.

http://dx.doi.org/10.1016/j.watres.2013.02.043
}

Please cite this article in press as: Calgua, B., et al., Detection and quantification of classic and emerging viruses by skimmedmilk flocculation and PCR in river water from two geographical areas, Water Research (2013), http://dx.doi.org/10.1016/ j.watres.2013.02.043 


\section{Introduction}

Microbiological pollution in water represents a health risk for human populations. Many viral infectious diseases are transmitted by consumption of or contact with water contaminated with sewage (Fong and Lipp, 2005). The discharge of untreated or even treated sewage into the aquatic environment is well known as the main cause of fecal pollution in water. The treatments commonly applied for wastewater depuration do not guarantee the absence of viral pathogens (Gantzer et al., 1998; Pusch et al., 2005; van den Berg et al., 2005; Bofill-Mas et al., 2006; Fumian et al., 2010).

Among the most frequently detected human viruses in water samples are the well-known groups of gastroenteric viruses: rotaviruses (RV) and noroviruses (NoV), together with the proposed human viral indicators (Puig et al., 1994; Pina et al., 1998; Bofill-Mas et al., 2000): human adenoviruses (HAdV) and JC polyomavirus (JCPyV). Furthermore, recent studies have shown that new and emerging viruses may also be present in water contaminated with sewage, such as: the new polyomaviruses Merkel cell, KI and WU (MCPyV, KIPyV and WUPyV); the new picornavirus klassevirus (KV); and an asfarvirus-like virus (Bofill-Mas et al., 2000; Miagostovich et al., 2008; Hotlz et al., 2009; Loh et al., 2009; Bofill-Mas et al., 2010b; Lodder et al., 2010; Wyn-Jones et al., 2011).

Rotavirus species A is considered the leading cause of severe diarrhea in children worldwide and according to the WHO, RV-diarrhea results in approximately half a million deaths and 2.4 million hospitalizations in developing countries each year (Parashar et al., 2009). RV are ubiquitous, they will have infected virtually all children by the time they reach 5 years of age regardless of socioeconomic status or geography; they are environmentally stable; and they are spread via direct or indirect contact with infected individuals (Schael et al., 2009). NoV are the leading cause of food-borne disease outbreaks worldwide; it is estimated that they cause $80-95 \%$ of all cases of gastroenteritis globally and may soon eclipse RV as the most common cause of severe pediatric gastroenteritis (Patel et al., 2008; Koo et al., 2010). NoVs are the major cause of sporadic outbreaks of infectious gastroenteritis and occasionally lead to hospitalization (Glass et al., 2009). Outbreaks tend to be most common in closed populations, such as childcare centers and cruise ships, and tend to involve children past infancy as well as adults (Khan and Bass, 2010; Glass et al., 2009). NoV are divided into five genogroups based on the phylogenetic analysis of the viral capsid (VP1) gene, and further subdivided into genetic clusters called genotypes. Genogroups I (GGI), II (GGII) and IV (GGIV) are the human strains (Glass et al., 2009; Koo et al., 2010). Despite this diversity, only a few strains, primarily those of genogroup II and genotype 4 (GGII.4), have been responsible for the majority of cases and outbreaks of food-borne infections in recent years (Barreira et al., 2010; Ferreira et al., 2010; Bull and White, 2011; Prado et al., 2011).

The DNA viruses HAdV and JCPyV have been proposed as human fecal/urine indicators in the environment (Puig et al., 1994; Pina et al., 1998; Bofill-Mas et al., 2000). They are ubiquitous as they are excreted by a high percentage of the human population. Several studies have reported an elevated prevalence of HAdV and JCPyV in water samples from different geographical areas (Bofill-Mas et al., 2000; AlbinanaGimenez et al., 2006; McQuaig et al., 2006; Miagostovich et al., 2008; McQuaig et al., 2009; Wyn-Jones et al., 2011). Although current policies concerning water quality include the use of bacterial indicators $E$. coli and intestinal enterococcus to evaluate microbiological water quality, various studies have shown that bacterial levels do not always correlate with viral presence. This is particularly so when the concentrations of fecal bacterial indicators are low and is probably due to the high environmental stability of HAdV and JCPyV (Brownell et al., 2007; Colford et al., 2007; Calgua et al., 2008; WynJones et al., 2011). HAdV are grouped into 7 species $(A-G)$, which have been widely reported to cause a broad range of clinical manifestations including respiratory tract infection, acute conjunctivitis, cystitis, gastroenteritis, and systemic infections. Antibodies against JCPyV were detected in over $80 \%$ of humans worldwide (Weber et al., 1997) and consequently their presence in water may not represent a significant health risk for most of the population. The pathogenicity of JCPyV is commonly associated with progressive multifocal leukoencephalopathy (PML) in immunocompromised states and has attracted attention due to its reactivation in some patients with multiple sclerosis and other autoimmune diseases when treated with immunomodulators (Berger and Major, 1999; Yousry et al., 2006). The kidneys and bone marrow are sites of chronic and latent infection with JCPyV, which is also excreted in the urine of healthy individuals and patients with PML (Kitamura et al., 1990; Koralnik et al., 1999).

MCPyV, KIPyV and WUPyV are novel viruses that have only recently been reported (Allander et al., 2007; Gaynor et al., 2007; Feng et al., 2008). Similarly to JCPyV, infection by these three viral agents is widespread among the human population (Babakir-Mina et al., 2009). They persist in a latent state in an unidentified body location and they can reactivate in a setting of immune suppression due to immunosuppressive drugs or other medical conditions (Babakir-Mina et al., 2009). KIPyV and WUPyV have been detected in the respiratory tract, suggesting that they might play a role in at least a subset of pneumonia infections in immunocompromised patients (Babakir-Mina et al., 2009). Moreover, they have been detected in various types of samples, including blood, feces, plasma and the tonsils (Babakir-Mina et al., 2009). Although KIPyV has been detected in lung cancer patients, only MCPyV has been strongly associated with being the primary human oncogenic polyomavirus candidate (Feng et al., 2008; Foulongne et al., 2008; Babakir-Mina et al., 2009), and has been found to be monoclonally integrated into the genome of Merkel cell carcinomas (Feng et al., 2008). Interestingly it has been suggested that MCPyV forms part of the skin microbiome in humans (Wieland et al., 2009; Schowalter et al., 2010; Moens et al., 2011; Foulongne et al., 2012). KIPyV, WUPyV and MCPyV have also been found in sewage samples, with MCPyV being detected most frequently (Bofill-Mas et al., 2010a,b), which could mean that it is more prevalent in silent infections or that it is a virus that is highly excreted.

The proposed new picornavirus KV was identified by deepsequencing in stool samples from Australia and the USA, and its presence was confirmed in urban sewage from Barcelona 
by PCR (Holtz et al., 2009). Phylogenetic analysis shows that KV is most closely related to the Aichi virus in the genus Kobuviru, a known cause of food-borne gastroenteritis in humans (Holtz et al., 2009; Greninger et al., 2009). KV has also been reported in South Korea, China and the USA (Northern California and Missouri), and in all cases it was associated with gastroenteritis in infants (Greninger et al., 2010; Han et al., 2010; Shan et al., 2010). Deep-sequencing also detected an asfarvirus-like virus in human serum from the Middle East and urban sewage from Barcelona (Loh et al., 2009). The Asfarviridae family (single double-stranded DNA) comprises a single genus with only one previously reported species, the asfarvirus, which primarily infects swine, leading to African swine fever. It is considered endemic to sub-Saharan Africa, but has been introduced to countries in Europe, South America and the Caribbean. Phylogenetic analyses show that ASFLV sequences are most closely related to the asfarvirus but are highly divergent from known asfarviruses (ASFV) strains. Therefore ASFLV is considered to be derived from at least one novel virus in the Asfarviridae family (Loh et al., 2009). Although ASFV is not known to infect humans even where the virus is endemic in pigs, identification of ASFLV in serum from multiple human patients suggests that human infection might occur.

The presence and concentration of viral pathogens in wastewater may vary according to the wastewater treatments, geographical area, season, and the hygiene and sanitary conditions. The use of new approaches in molecular detection such as viral metagenomics studies of stools (Finkbeiner et al., 2008), urban sewage (Cantalupo et al., 2011) and water matrices (Rosario et al., 2009) indicate that the number of viruses reported to date is tiny compared to the results of the new studies.

The recovery of viruses from water samples such as river water, seawater and groundwater, where fecal contamination could be low or moderate, requires the concentration of viruses from several liters of sample into a much smaller volume. Probably the most frequently used procedures to concentrate viruses are the two-step methods based on adsorption-elution protocols with a second concentration step, commonly by organic flocculation with beef extract. Those methods include the use of electropositive or negative nitrocellulose membranes or cartridges, glass wool and fiber glass (Sobsey et al., 1973; Vilaginès et al., 1993; Pallin et al., 1997; Lambertini et al., 2008; Albinana-Gimenez et al., 2009). Albinana-Gimenez et al. (2009) reported that glass wool columns are more efficient than the electropositive filters tested in the study; they recovered HAdV (1.21\%) and JCPyV (13.7\%) by qPCR from $50 \mathrm{~L}$ of fresh water. Lambertini et al. (2008), also using a glass wool method, obtained viral recoveries of $70 \%$, $21 \%$ and $29 \%$, for poliovirus, adenovirus 41 and norovirus respectively. Haramoto et al. (2004) and Katayama et al. (2002) described two-step methods using electronegative membranes, an inorganic elution with $1 \mathrm{M} \mathrm{NaOH}$ and finally a second concentration step using Centripep. They reported viral recoveries for poliovirus of around 90\%. Calgua et al. (2008) describe a one-step concentration method based on organic flocculation with skimmed milk to concentrate viruses from $10 \mathrm{~L}$ of seawater and reported a viral recovery of $50 \%$ for HAdV by qPCR. The protocol using skimmed-milk flocculation presented good recoveries from seawater and lower intra-laboratory variability than other common procedures (Girones et al., 2010), it is also more simple, has a lower cost and is a useful protocol for the routine analysis of large numbers of samples.

In the present study, human viruses grouped into emerging viruses (KIPyV, WUPyV, MCPyV, KV and ASFLV), classical gastroenteritis agents (NoV, RV) and human viral fecal indicators (HAdV and JCPyV) were detected in river water samples from two different geographical areas with very different hydrological and climate conditions (Barcelona, Spain and Rio de Janeiro, Brazil). The procedure initially reported to concentrate viral particles from seawater (Calgua et al., 2008) was adapted and validated for use with a wide range of fresh water matrices and viruses of public health interest.

\section{Materials and methods}

\subsection{Virus}

Viruses for use in the recovery assays were initially isolated from clinical samples and were as follows: HAdV 2 (originally provided by Annika Allard, Umeå University, Sweden, and in Brazil kindly provided by Dr. José Paulo Leite, LVCA, Fiocruz, Brazil), JCPyV strain Mad-4 (originally provided by Dr. Eugene O. Major, NINDS, National Institutes of Health, MD, USA), NoV GGII (fecal samples kindly provided by Annika Allard, Umeå University, Sweden and by Dr. José Paulo Leite, LVCA, Fiocruz, Brazil) and RVA G1P[8] (fecal samples provided by Dr. José Paulo Leite, LVCA, Fiocruz, Brazil). HAdV 2 was also used as a control. HAdV 2 and JCPyV Mad-4 were cultured in A549 (epithelial cell line derived from human lung carcinoma) and SVG-A cells (fibroblast cell line subcloned from the original SVG human fetal glial cell line), respectively. The cell lines were grown in Earle's minimum essential medium (EMEM) supplemented with $1 \%$ glutamine, $50 \mu$ g of gentamicin/mL and $10 \%$ (growth medium) or $2 \%$ (maintenance medium) of heatinactivated fetal bovine serum.

\subsection{Water samples}

For validation assays of the virus concentration method, approximately forty 5-L river samples, 20 in each laboratory were used. In order to analyze viral contamination in field samples from two geographical areas, six 10-L river water samples were collected over one month and analyzed in each laboratory for the selected viruses. River water samples ( 5 and $10 \mathrm{~L})$ were collected from two different geographical areas: the Llobregat river in Barcelona, Spain, a Mediterranean area; and the Macacos and Fairas Timbó rivers in the urban area of Rio de Janeiro, Brazil. Samples from Barcelona and Rio de Janeiro were collected on two different days in March in every location. The selected sampling site in Barcelona corresponds with a source of water at the entrance to a drinking water treatment plant. Moreover, upstream from the point there are more than 30 sewage treatment plants that discharge secondary effluents into the river. The Llobregat river has a flow rate of $16.9 \mathrm{~m}^{3} / \mathrm{s}$ and is $170 \mathrm{~km}$ long. Samples from Rio de Janeiro were also collected in March. Both Brazilian rivers, the Macacos and Farias Timbó, receive domestic sewage 
discharge from urbanized areas in Rio de Janeiro. The Macacos river, which is less polluted, flows through the Tijuca rainforest and into Rodrigo de Freitas Lagoon to the south of the city. The Farias Timbó river is a highly polluted river that flows through the greater metropolitan and slum area of the city of Rio de Janeiro, in a northerly direction. It receives a high load of untreated domestic sewage discharge. It flows into Cunha channel, and finally in Guanabara Bay, in the Atlantic Ocean.

Samples were collected according to ISO 19458 (2006). Water samples for microbiological analysis were stored for a maximum of $24 \mathrm{~h}$ at $4{ }^{\circ} \mathrm{C}$ before being processed. Samples collected in Barcelona showed turbidity and conductivity values between 6.18 and $44.5 \mathrm{NTU}$ and 588-1360 mS respectively; while the samples from Rio de Janeiro had values of 1 NTU and between 490 and $830 \mathrm{mS}$.

\subsection{Virus concentration by skimmed milk (SM) flocculation procedure}

Water samples with high levels of organic matter (by simple observation) such as leaves, algae or sand, were left to settle for two hours and the clear water was then transferred to a new container to start the concentration protocol. The conductivity of all the samples was measured before starting the virus concentration protocol, and samples with conductivity $\leq 1.5 \mathrm{mS}$ were conditioned by adding artificial sea salts (Sigma, Aldrich Chemie GMBH, Steinheim, Germany) to obtain values $\geq 1.5 \mathrm{mS}$.

The river water samples were then concentrated based on a procedures described previously by Calgua et al. (2008) and Bofill-Mas et al. (2011). Briefly, once the samples were conditioned, a pre-flocculated $1 \%(\mathrm{w} / \mathrm{v})$ skimmed milk solution (PSM) was prepared by dissolving $10 \mathrm{~g}$ skimmed milk powder (Difco, Detroit, MI, USA) in $1 \mathrm{~L}$ of artificial seawater at pH 3.5 (Sigma, Aldrich Chemie GMBH, Steinheim, Germany). The sample was then carefully acidified to $\mathrm{pH} 3.5$ by adding $\mathrm{HCl} 1 \mathrm{~N}$. The PSM was added to each of the previously conditioned samples until the final concentration of skimmed milk in the sample was $0.01 \%(\mathrm{w} / \mathrm{v})$. Samples were stirred for $8 \mathrm{~h}$ at room temperature and flocs were allowed to form sediment by gravity for another $8 \mathrm{~h}$. The supernatant was carefully removed using a vacuum pump without disturbing the sediment. The final volume of about $500 \mathrm{~mL}$ containing the sediment was transferred to a centrifuge tube and centrifuged at $7000 \times \mathrm{g}$ for $30 \mathrm{~min}$ at $12{ }^{\circ} \mathrm{C}$. The supernatant was carefully removed and the pellet dissolved in phosphate buffer $\left(1: 2, \mathrm{v} / \mathrm{v}\right.$ of $\mathrm{Na}_{2} \mathrm{HPO}_{4} 0.2 \mathrm{M}$ and $\mathrm{NaH}_{2} \mathrm{PO}_{4} 0.2 \mathrm{M}$ ) at pH 7.5, at a ratio of $1 \mathrm{~mL}$ of phosphate buffer per $1 \mathrm{~L}$ of concentrated sample. The viral concentrate was stored at $-80^{\circ} \mathrm{C}$. When necessary, an aliquot of the clarified phase of PSM was used to balance the centrifuge pots.

\subsection{Validation of SM-flocculation procedure for detecting viruses in river water}

In order to validate the use of the SM-flocculation procedure in river water, assays to evaluate the reproducibility and repeatability of viral recovery were performed in two laboratories in different geographical areas: Barcelona and Rio de Janeiro. A total of approximately 40 samples were tested, 20 in each laboratory. Each laboratory used two sets of ten 5 -
$\mathrm{L}$ river water samples, each set having been collected on different days and then mixed together. Based on the recovery assays described by Lambertini et al. (2008), sets of ten samples were divided into three groups as follows. (i) Six samples to test viral recovery. These samples were spiked at the same time with viral suspensions of HAdV 2, JCPyV Mad4, NoV GGII in Barcelona and HAdV 2, RV and NoV GGII in Río de Janeiro. (ii) Three non-spiked samples were treated to concentrate the viral particles, after which the viral concentrates were spiked as above. The idea here was to extract nucleic acids and quantify viral genomes under the same conditions as the spiked samples in (i). These conditions allow to be averted false estimates of viral recovery due to nucleic acid extractions and qPCR quantification, and therefore the values obtained (Fig. 1) were taken as the reference spiked viral quantity (i.e. $100 \%$ recovery). (iii) One sample was used to analyze the endogenous viruses present in the set of samples, and the values obtained together with the samples in groups (i) and (ii) were used to estimate viral recovery.

\subsection{Nucleic acid extractions}

Nucleic acids (DNA and RNA) were extracted using the QIAamp Viral RNA kit (Qiagen, Valencia, USA) according to the manufacturer's instructions, using $140 \mu \mathrm{L}$ of viral concentrate or viral suspension and eluting the resulting nucleic acid extraction in $80 \mu \mathrm{L}$ of elution buffer. Nucleic acid extractions were analyzed immediately or stored at $-80^{\circ} \mathrm{C}$ until further analysis.

\subsection{Enzymatic detection and amplification of viruses}

Based on previously reported sequences and their specificity against related viruses, oligonucleotides for ASFLV and KV were designed for nested PCR (nPCR) and reverse transcription (RT)-nPCR, respectively (Table 1). For RNA viruses, the first rounds of enzymatic amplifications were performed using OneStep RT-PCR Kit (Qiagen, Hilden, Germany) following the manufacturer's instructions. While in the first round of DNA amplification, $40 \mu \mathrm{L}$ of amplification mix contained: PCR Buffer $1 \times, \mathrm{MgCl}_{2} 1.5 \mathrm{mM}, 250 \mu \mathrm{M}$ of each dNTP, $0.5 \mu \mathrm{M}$ of the specific primer for the virus analyzed, and 4 units of Taq Gold DNA polymerase (Applied Biosystems, Foster, CA, USA). In the first round of either PCR or RT-PCR, $10 \mu \mathrm{L}$ of undiluted nucleic acid extract and a 10-fold dilution was analyzed.

In the second round of enzymatic amplification, $2 \mu \mathrm{L}$ of the product obtained in the first round was added to $48 \mu \mathrm{L}$ of amplification mix containing a set of specific primers for each virus and the same reagent composition described above. The amplification conditions were as follows: $95^{\circ} \mathrm{C}$ for $10 \mathrm{~min}, 30$ cycles of $94^{\circ} \mathrm{C}$ for $60 \mathrm{~s}$, annealing temperature for $60 \mathrm{~s}$, and $72{ }^{\circ} \mathrm{C}$ for $60 \mathrm{~s}$, and finally $7 \mathrm{~min}$ at $72{ }^{\circ} \mathrm{C}$.

Nested PCR, (RT)-nPCR and quantitative PCR assays for the other viruses were performed according to previous studies (Tables 2 and 3) in which they were applied to environmental samples such as river water, groundwater, seawater, sewage and drinking water (Bofill-Mas et al., 2000; Bofill-Mas et al., 2003; Albinana-Gimenez et al., 2006; Bofill-Mas et al., 2006; 

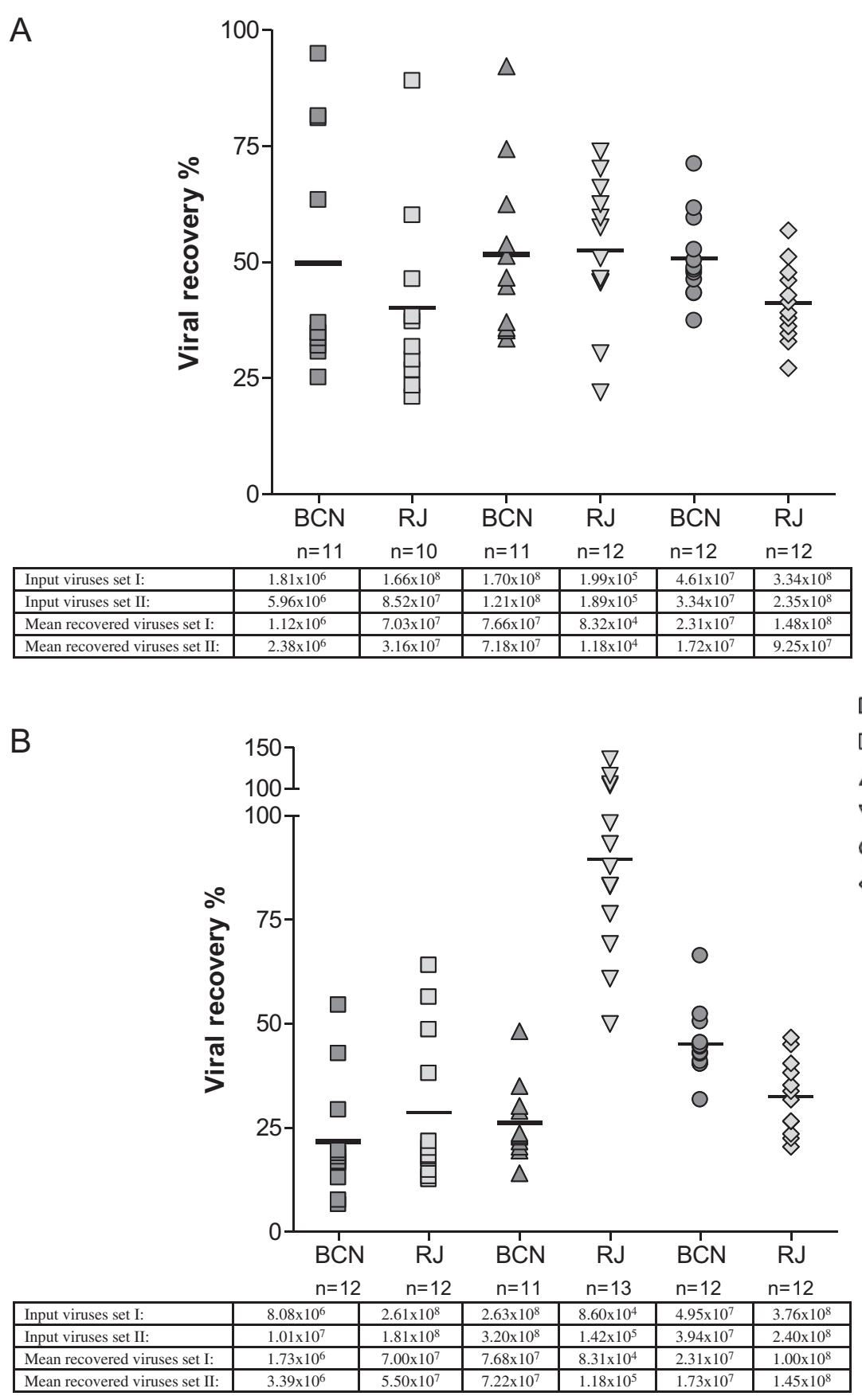

$\square$ BCNHAdV

$\square$ RJ HAdV

$\triangle \mathrm{BCNNOV}$

$\nabla$ RJ NoV

- BCN JCPyV

$\diamond$ RJ RV

Fig. 1 - Inter-and-intra laboratory assays to evaluate the viral recovery of virus concentration procedure by qPCR. (A) viral recovery when results from spiked-viral concentrates were defined as $100 \%$ of input virus. (B) Viral recovery when results from viral suspensions were defined as $100 \%$ of input virus. Tables show the concentrations (GC/mL) of viruses added and recovered for each set. Values in the columns correspond with assays for each laboratory described in the graphic above.

Albinana-Gimenez et al., 2009; Calgua et al., 2008; Bofill-Mas et al., 2010a; Wyn-Jones et al., 2011; Fumian et al., 2011; Lambertini et al., 2008). Each qPCR assay applied contained a set of specific primers and a TaqMan ${ }^{\circledR}$-fluorogenic probe.

The nucleic acids from the samples were analyzed undiluted, 10- and when necessary 100-fold diluted. Each sample was run in duplicate (4-6 runs/sample). In all qPCRs or RTqPCRs, the amount of DNA or RNA in GC/mL was defined as the mean of the data obtained. Non-template and inhibition controls were included in each run. The inhibition controls were extra aliquots of the nucleic acids extracted from one sample with standard DNA added.

\subsection{Sequencing products}

Products obtained after nPCR were purified using the QIAquick PCR purification kit (Qiagen, Valencia, USA). Both strands of the purified DNA amplicons were sequenced with 
Table 1 - Primers designed for molecular detection of klassevirus (KV) and asfarvirus-like virus (ASFLV).

\begin{tabular}{|c|c|c|c|c|}
\hline Virus & Primer & Sequence $5^{\prime}-3^{\prime}$ & Region on the genome & Position $^{b}$ \\
\hline \multirow[t]{8}{*}{ KV } & LG0119a (1st round PCR) & GCTAACTCTAATGCTGCCACC & VP & 1933-1953 \\
\hline & KV-VP-R (1st round PCR) & GAGGTCCAGGTCAAGTTCC & Amplicon size & 2319-2337 \\
\hline & KV-VPn-F (2nd round PCR) & GAAGGACTCCACAACTATTGG & 404pb1st round PCR (primers $\mathrm{T}_{\mathrm{a}}: 55^{\circ} \mathrm{C}$ ) & 1997-2017 \\
\hline & KV-VPn-R (2nd round PCR) & CATAGAAAGCTGAGTCAATAGG & 123pb2nd round PCR (primers $\mathrm{T}_{\mathrm{a}}: 55^{\circ} \mathrm{C}$ ) & $2099-2120$ \\
\hline & LG0118 ${ }^{a}$ (1st round PCR) & ATGGCAACCCTGTCCCTGAG & $3 \mathrm{D}$ & $6795-6814$ \\
\hline & KV-3D-R (1st round PCR) & TCCAGAACACGACCAGGTTGG & Amplicon size & 7177-7197 \\
\hline & KV-3Dn-F (2nd round PCR) & GATACAAGCAATTGTAGTCG & 402pb1st round PCR (primers $\mathrm{T}_{\mathrm{a}}: 60^{\circ} \mathrm{C}$ ) & $6940-6959$ \\
\hline & KV-3Dn-R (2nd round PCR) & TAGACCAGACATTAGAGAAGG & 157pb2nd round PCR (primers $T_{\mathrm{a}}: 58^{\circ} \mathrm{C}$ ) & 7077-7097 \\
\hline \multirow[t]{4}{*}{ ASFLV } & ASFLV-Pol-F (1st round PCR) & GAATTGAAGGATCTAATGAAACC & Polymerase & $10-32$ \\
\hline & ASFLV-Pol-R (1st round PCR) & GGCAGGAAGATCCACATGAAC & Amplicon size & $320-340$ \\
\hline & ASFLV-Pol-nF (2nd round PCR) & GCGGCTATCAATTGAATCCC & 330 pb1st round PCR (primers $\mathrm{T}_{\mathrm{a}}: 6{ }^{\circ} \mathrm{C}$ ) & $50-69$ \\
\hline & ASFLV-Pol-nR (2nd round PCR) & CGGCCAATACAATATTCAACTCG & $195 \mathrm{pb} 2$ nd round PCR (primers $\mathrm{T}_{\mathrm{a}}: 58^{\circ} \mathrm{C}$ ) & $223-245$ \\
\hline
\end{tabular}

the ABI PRISM ${ }^{\mathrm{TM}}$ Dye Terminator Cycle Sequencing Ready Reaction kit with Ampli Taq ${ }^{\circledR}$ DNA polymerase FS (PerkinElmer, Applied Biosystems, Foster, CA, USA) following the manufacturer's instructions. The results were analyzed using the ABI PRISM 3730 XL automated sequencer (PerkinElmer, Applied Biosystems).

\subsection{Phylogenetic studies}

The Merkel cell virus nucleotide sequences introduced in this work (corresponding to the VP2/VP3-VP1 junction) were analyzed with representative sequences of human polyomaviruses obtained from GenBank. Codon-based alignments

Table 2 - Sequences of primers used to detect viruses in water by nPCR assays.

\begin{tabular}{|c|c|c|c|}
\hline Virus & Target region & Primers $5^{\prime}-3^{\prime}$ (position) & Reference \\
\hline HAdV & Hexon protein ${ }^{a}$ & $\begin{array}{l}\text { Hex1deg: GCCSCARTGGKCWTACATGCACATC (18858-18882) } \\
\text { Hex2deg: CAGCACSCCICGRATGTCAAA 19138-19158) } \\
\text { neHex3ded: GCCCGYGCMACIGAIACSTACTTC (18931-18954) } \\
\text { neHex4deg: CCYACRGCCAGIGTRWAICGMRCYTTGTA (19077-19102) }\end{array}$ & Allard et al., 2001 \\
\hline JCPyV & Regulatory region ${ }^{\mathrm{b}}$ & $\begin{array}{l}\text { JR1: CCCTATTCAGCACTTTGTCC }(4992-5011) \\
\text { JR2: CAAACCACTGTGTCTCTGTC }(428-447) \\
\text { JR3: GGGAATTTCCCTGGCCTCCT }(5060-5079) \\
\text { JR4: ACTTTCACAGAAGCCTTACG }(297-317)\end{array}$ & Bofill-Mas et al., 2001 \\
\hline NoV GGII & $\operatorname{RdRp}^{c}$ & $\begin{array}{l}\text { JV12Y: ATACCACTATGATGCAGAYTA }(4279-4299) \\
\text { JV13Y: TCATCATCACCATAGAAIGAG }(4878-4858) \\
\text { Ni-R: AGCCAGTGGGCGATGGAATTC }(4515-4495)\end{array}$ & Vennema et al., 2002 \\
\hline RV-A & $\mathrm{VP}^{\mathrm{d}}$ & $\begin{array}{l}\text { VP6F: GACGGVGCRACTACATGGT (747-766) } \\
\text { VP6R: GTCCAATTCATNCCTGGTTGG (1126-1106) } \\
\text { VP6NF: GCWAGAAATTTTGATACA (867-884) } \\
\text { VP6NR: GATTCACAAACTGCAGA (1005-1021) }\end{array}$ & $\begin{array}{l}\text { Iturriza-Gomara et al., } 2002 \\
\text { and Gallimore et al., } 2006\end{array}$ \\
\hline MCPyV & $\mathrm{VP} 1 / 2 / 3^{\mathrm{e}}$ & $\begin{array}{l}\text { MC1c: GAATTAACTCCCATTCTTGGATTCA }(4228-4252) \\
\text { MC2c: TTGGCTTCTTCCTCTGGTACT }(4492-4472) \\
\text { MC3c: ATTTGGGTAATGCTATCTTCTCC }(4264-4286) \\
\text { MC3c: GGATATATTTCTCCTGAATTACA }(4461-4439)\end{array}$ & Bofill-Mas et al., 2010a,b \\
\hline KIPyV & $V P 1^{f}$ & $\begin{array}{l}\text { KI1: GCTGCTCAGGATGGGCGTGA }(1684-1704) \\
\text { KI2: CAGKGTTCTAGGGTCTCCTGGT }(2061-2043) \\
\text { KI3: GTTGCTTGTTGTACCTCTAG }(1899-1918) \\
\text { KI4: AATTGTATAGGTAGTTGGGCCT }(2088-2067)\end{array}$ & Bofill-Mas et al., 2010a,b \\
\hline WUPyV & $\mathrm{VP}^{\mathrm{g}}$ & $\begin{array}{l}\text { WU1: CCCACAAGAGTGCAAAGCCTTC }(1730-1750) \\
\text { WU2: AGGCACAGTACCATTGGTTTTA }(2234-2213) \\
\text { WU3: AGTTTTGGTGCTTCCTKTSC }(2044-2063) \\
\text { WU4: TACAGTATACTGAGCAGGC (22072118) }\end{array}$ & Bofill-Mas et al., 2010a,b \\
\hline \multicolumn{4}{|c|}{$\begin{array}{l}\text { Position according to GenBank virus sequence. } \\
\text { a (DQ315364.2). } \\
\text { b (Frisque et al., 1984). } \\
\text { c (AF356599). } \\
\text { d (Iturriza-Gomara et al., 2002). } \\
\text { e (EU375803). } \\
\text { f (EF127906). } \\
\text { g (EF444549). }\end{array}$} \\
\hline
\end{tabular}

Please cite this article in press as: Calgua, B., et al., Detection and quantification of classic and emerging viruses by skimmedmilk flocculation and PCR in river water from two geographical areas, Water Research (2013), http://dx.doi.org/10.1016/ j.watres.2013.02.043 
Table 3 - Sequences of primers and probes used to quantify viruses in water by qPCR assays.

\begin{tabular}{|c|c|c|c|}
\hline Virus & Target region & Primers and probes $5^{\prime}-3^{\prime}$ (position) & Reference \\
\hline \multirow[t]{3}{*}{ HAdV } & qPCR (hexon & AdF: CWTACATGCACATCKCSGG (17629-17647) & Hernroth et al., 2002 \\
\hline & protein $)^{\mathrm{a}}$ & AdR: CRCGGGCRAAYTGCACCAG (17679-17697) & \\
\hline & & AdP: FAM-CCGGGCTCAGGTACTCCGAGGCGTCCT-BHQ1 (17650-17676) & \\
\hline \multirow[t]{3}{*}{ JCPyV } & qPCR (Large T & JE3F: ATGTTTGCCAGTGATGATGAAAA (4339-4317) & Pal et al., 2006 \\
\hline & antigen) $)^{\mathrm{b}}$ & JE3R: GGAAAGTCTTTAGGGTCTTCTACCTTT (4251-4277) & \\
\hline & & $\begin{array}{l}\text { JE3P: FAM-AGGATCCCAACACTCTACCCCACCTAAAAAGA-BHQ1 (4313 } \\
\text {-4482) }\end{array}$ & \\
\hline \multirow[t]{3}{*}{ NoV GGII } & qPCR (ORF1-ORF2) ${ }^{\mathrm{c}}$ & JJV2F: CAAGAGTCGATGTTTAGGTGGATGAG (5003-5028) & Johtikumar et al., 2006 \\
\hline & & COG2R: TCGACGCCATCTTCATTCACA (5080-5100) & \\
\hline & & RING2: FAM-TGGGAGGGCGATCGCAATCT-BHQ1 (5048-5067) & \\
\hline \multirow[t]{3}{*}{ RV-A } & qPCR (NSP3) ${ }^{\mathrm{d}}$ & NSP3f: ACCATCTWCACRTRACCCTCTATGAG (963-988) & Zeng et al., 2008 \\
\hline & & NSP3r: GGTCACATAACGCCCCTATAGC (1028-1049) & \\
\hline & & NSP3p: FAM-AGTTAAAAGCTAACACTGTCAAA-MGB (995-1017) & \\
\hline \multicolumn{4}{|c|}{$\begin{array}{l}\text { Position according to GenBank virus sequence. } \\
\text { a (DQ315364.2). } \\
\text { b (NC_001699.1). } \\
\text { c (X86557). } \\
\text { d (X81436). }\end{array}$} \\
\hline
\end{tabular}

of nucleotide sequences were determined using Prankster software (Löytynoja and Goldman, 2005) and edited using the Bioedit v7.0.9.0 program (Hall, 1999). A maximum likelihood (ML) phylogenetic tree was obtained using PhyML software v3.0 (Guindon et al., 2010) with the substitution model estimated by the jModelTest software v0.1.1 (Posada, 2008) according to the Akaike Information Criterion (AIC). The robustness of the phylogenetic grouping was evaluated by bootstrap analysis using ML (1000 replicates) and the PhyML software.

\subsection{Statistical analysis}

Analysis of variance (one- and two-way ANOVA tests) was used to evaluate differences between recovery rates through intra- and inter-laboratory assays. The Shapiro-Wilks and Bartlett tests were used to test for normality and homogeneity of variance in the ANOVA procedures. $P$-values of $<0.05$ were considered significant. The statistical analysis was performed using R software version 2.14.1 (Verzani, 2004; R, 2008).

\section{Results}

3.1. Inter- and intra-laboratory variability of viral recovery values for SM flocculation procedure for detecting viruses in river water

Values of intra- and inter-laboratory variability in the viral recovery of HAdV 2 and NoV GGII showed low variability according with values described for virus concentration methods by Calgua et al. (2013), with mean values of 50\% (25-95\% [mean: $\left.1.80 \times 10^{6} ; 1.50 \times 10^{6}-1.72 \times 10^{6} \mathrm{GC} / \mathrm{mL}\right] ; \mathrm{SD}=24.21$; coefficient of variation $[\mathrm{CV}]=48.47 \%)$ and $41 \%\left(21-89 \%\right.$ [mean: $5.48 \times 10^{7}$; $\left.\left.5.26 \times 10^{7}-1.48 \times 10^{8} \mathrm{GC} / \mathrm{mL}\right] ; \mathrm{SD}=20.70 ; \mathrm{CV}=51.44 \%\right)$ for HAdV, and 52\% (34-74\% [mean: $7.45 \times 10^{7}$; $\left.\left.5.70 \times 10^{7}-1.26 \times 10^{8} \mathrm{GC} / \mathrm{mL}\right] ; \mathrm{SD}=18.45 ; \mathrm{CV}=35.78 \%\right)$ and $53 \%$ (22-73\% [mean: $1.01 \times 10^{5} ; 4.30 \times 10^{4}-1.40 \times 10^{5} \mathrm{GC} / \mathrm{mL}$; $\mathrm{SD}=15.59$; $\mathrm{CV}=29.68 \%$ ) for NoV, in Barcelona and Rio de
Janeiro, respectively (Fig. 1). The mean recovery of JCPyV in Barcelona was 51\% (38-71\% [mean: $2.02 \times 10^{7}$; $\left.1.25 \times 10^{7}-3.28 \times 10^{7} \mathrm{GC} / \mathrm{mL}\right] ; \mathrm{SD}=9.26 ; \mathrm{CV}=18.23 \%$ ), and for RV tested in Rio de Janeiro the mean recovery was 41\% (27-57\% [mean: $1.18 \times 10^{8} ; 6.38 \times 10^{7}-1.90 \times 10^{8} \mathrm{GC} / \mathrm{mL}$ ]; $\mathrm{SD}=8.33$; $\mathrm{CV}=20.24 \%$; both recovery values showed low variability (Fig. 1a). Whereas that the recovery values estimated by the quantitation from the raw data directly using the viral suspension (Fig. 1b) were 22\% (7-54\% [mean input: $9.45 \times 10^{6}$; mean recovered: $\left.2.06 \times 10^{6} ; 7.58 \times 10^{5}-4.80 \times 10^{6} \mathrm{GC} / \mathrm{mL}\right]$; $\mathrm{SD}=14.11 ; \mathrm{CV}=65,9 \%)$ and $29 \%$ (12-64\% [mean input: $2.21 \times 10^{8} ;$ mean recovered: $6.25 \times 10^{7} ; 2.27 \times 10^{7}-1.16 \times 10^{8} \mathrm{GC} /$ $\mathrm{mL}] ; \mathrm{SD}=18.24 ; \mathrm{CV}=63,77 \%)$ for HAdV, and $26 \%(14-48 \%$ [mean input; $2.91 \times 10^{8} ;$ mean recovered: $7.47 \times 10^{7}$; $\left.\left.4.50 \times 10^{7}-1.27 \times 10^{8} \mathrm{GC} / \mathrm{mL}\right] ; \mathrm{SD}=9.25 ; \mathrm{CV}=35.31 \%\right)$ and $89 \%$ (50-135\% [mean input: $1.14 \times 10^{5}$; mean recovered: $1.02 \times 10^{5}$; $\left.\left.4.29 \times 10^{4}-1.17 \times 10^{5} \mathrm{GC} / \mathrm{mL}\right] ; \mathrm{SD}=23.14 ; \mathrm{CV}=25.87 \%\right)$ for $\mathrm{NoV}$, in Barcelona and Rio de Janeiro, respectively. For JCPyV the values were $45 \%\left(66-31 \%\right.$ [mean input: $4.44 \times 10^{7}$; mean recovered: $\left.2.02 \times 10^{7} ; 1.25 \times 10^{7}-3.28 \times 10^{7} \mathrm{GC} / \mathrm{mL}\right] ; \mathrm{SD}=8.43$; $\mathrm{CV}=18.54 \%)$ and for RV $32.59 \%$ (20-47\% [mean input: $3.08 \times 10^{8}$; mean recovered: $2.02 \times 10^{7} ; 7.68 \times 10^{7}-1.76 \times 10^{8} \mathrm{GC} /$ $\mathrm{mL}] ; \mathrm{SD}=8.86 ; \mathrm{CV}=27.19 \%$ ).

\subsection{Distribution of viruses in river water}

To evaluate the viral contamination in the geographical areas studied and during March, six 10-L river water samples per laboratory were treated to concentrate the viruses. A list of the viruses detected in each laboratory is given in Table 4. The average values given were calculated only from the positive samples.

\subsubsection{Human fecal viral indicators HAdV and JCPyV}

HAdV and JCPyV were detected in $100 \%$ of the samples analyzed in Barcelona (6/6) and Rio de Janeiro (6/6). In Barcelona the mean concentration of HAdV and JCPyV was $6.43 \times 10^{3} \mathrm{GC} / \mathrm{L}\left(1.99 \times 10^{3}-1.18 \times 10^{4} \mathrm{GC} / \mathrm{L}\right)$ and $1.05 \times 10^{4} \mathrm{GC} / \mathrm{L}$ $\left(4.40 \times 10^{3}-1.49 \times 10^{4} \mathrm{GC} / \mathrm{L}\right)$, respectively (Table 4$)$. In Rio de 
Table 4 - Virus detected in river water from Barcelona and Rio de Janeiro.

\begin{tabular}{|c|c|c|c|c|c|c|c|c|c|c|}
\hline \multirow[t]{2}{*}{ Site } & \multirow{2}{*}{$\begin{array}{l}\text { River water } \\
\text { sample }\end{array}$} & \multicolumn{9}{|c|}{ Viruses analyzed } \\
\hline & & HAdV GC/L & JCPyV GC/L & NoV GGII GC/L & RV GC/L & $\begin{array}{l}\text { MCPyV } \\
\text { nPCR }\end{array}$ & $\begin{array}{l}\text { KIPyV } \\
\text { nPCR }\end{array}$ & $\begin{array}{l}\text { WUPyV } \\
\text { nPCR }\end{array}$ & $\begin{array}{c}\mathrm{KV} \\
\mathrm{nPCR}\end{array}$ & $\begin{array}{l}\text { ASFLV } \\
\text { nPCR }\end{array}$ \\
\hline \multirow[t]{6}{*}{ BCN } & BCN1a0309 & $7.90 \times 10^{3}$ & $9.40 \times 10^{3}$ & $1.27 \times 10^{3}$ & NT & - & - & - & - & - \\
\hline & BCN2a0309 & $1.10 \times 10^{4}$ & $1.21 \times 10^{4}$ & - & NT & + & - & - & - & - \\
\hline & BCN3a0309 & $1.18 \times 10^{4}$ & $1.49 \times 10^{4}$ & $2.93 \times 10^{3}$ & NT & + & - & - & - & - \\
\hline & BCN4b0309 & $1.99 \times 10^{3}$ & $4.40 \times 10^{3}$ & $1.04 \times 10^{4}$ & NT & + & - & - & - & - \\
\hline & BCN5b0309 & $2.48 \times 10^{3}$ & $1.21 \times 10^{4}$ & $1.47 \times 10^{5}$ & NT & - & - & - & - & - \\
\hline & BCN6b0309 & $3.46 \times 10^{3}$ & $9.94 \times 10^{3}$ & $8.95 \times 10^{4}$ & NT & - & - & - & - & - \\
\hline \multirow[t]{6}{*}{ RDJ } & RJN1a09a & $7.11 \times 10^{4}$ & $1.58 \times 10^{2}$ & $8.57 \times 10^{3}$ & $2.70 \times 10^{4}$ & - & - & - & - & - \\
\hline & RJN2a09a & $1.47 \times 10^{4}$ & $1.07 \times 10^{3}$ & $6.76 \times 10^{3}$ & $1.63 \times 10^{4}$ & + & - & - & - & - \\
\hline & RJN3b09a & $1.59 \times 10^{3}$ & $1.98 \times 10^{4}$ & - & - & + & - & - & + & - \\
\hline & RJN4b09a & $3.98 \times 10^{4}$ & $2.97 \times 10^{4}$ & - & - & + & - & - & + & - \\
\hline & RJN5b09b & $1.11 \times 10^{4}$ & $2.82 \times 10^{3}$ & - & $7.29 \times 10^{2}$ & - & - & - & - & + \\
\hline & RJN6b09b & $7.13 \times 10^{2}$ & $2.71 \times 10^{3}$ & - & $1.11 \times 10^{3}$ & - & - & - & - & - \\
\hline \multicolumn{11}{|c|}{$\begin{array}{l}\text { NT: Not tested. } \\
\text { a Farias Timbó river. } \\
\text { b Macacos River river. }\end{array}$} \\
\hline
\end{tabular}

Janeiro the mean concentrations of HAdV and JCPyV were $2.31 \times 10^{4} \mathrm{GC} / \mathrm{L}\left(7.13 \times 10^{2}-7.11 \times 10^{4} \mathrm{GC} / \mathrm{L}\right)$ and $9.38 \times 10^{3} \mathrm{GC} / \mathrm{L}$ $\left(1.58 \times 10^{2}-2.97 \times 10^{4} \mathrm{GC} / \mathrm{L}\right)$, respectively (Table 4$)$. Four out of the six positive qPCR results for HAdV were sequenced and using the BLAST tool. It identified three samples as HAdV 41 and one samples as HADV 40, showing a similarity of about 95-99\% over $99-98 \%$ of sequence coverage. For JCPyV, 3/6 samples were sequenced and the strains identified by BLAST showed the expected archetypical structure in the regulatory region (Bofill-Mas et al., 2001).

\subsubsection{Emerging viruses KIPyV, WUPyV, MCPyV, KV and ASFLV}

As shown in Table 4, MCPyV was detected in $50 \%$ of the river samples from Barcelona (3/6) and Río de Janeiro (3/6). KIPyV and WUPyV were not detected in Barcelona or Rio de Janeiro. $\mathrm{KV}$ and ASFLV were detected in 33\% (2/6) and 16\% (1/6), respectively, of the samples from Rio de Janeiro and were not detected in river water from Barcelona. The sequence analysis using BLAST showed a similarity of about 95-99\% over 96-98\% of sequence coverage with the corresponding target sequences present in GenBank.

\subsubsection{Common gastroenteritis viral agents NoV GGII and RV} The results for NoV and RV are also presented in Table 4. NoV GGII were detected at a concentration of $5.02 \times 10^{4} \mathrm{GC} / \mathrm{L}$ $\left(1.27 \times 10^{3}-1.47 \times 10^{5} \mathrm{GC} / \mathrm{L}\right)$ in $83 \%(5 / 6)$ of the samples from Barcelona. In Rio de Janeiro NoV were detected in 33\% (2/6) of the river samples with a mean value of $7.66 \times 10^{3} \mathrm{GC} / \mathrm{L}$. In Rio de Janeiro RV were detected and quantified in $67 \%(4 / 6)$ of the river samples at a concentration of $1.13 \times 10^{3} \mathrm{GC} / \mathrm{L}$ $\left(7.29 \times 10^{2}-2.70 \times 10^{4} \mathrm{GC} / \mathrm{L}\right)$. Selected positive samples for NoV GGII from Barcelona (4/5) were sequenced and the results as analyzed using BLAST showed that three samples were NoV GGII.4 and one was NoV GGII.12. Positive samples of NoV from Rio de Janeiro were not sequenced. Sequence analysis for RVA showed 99\% similarity with RVA genotype I2, which is generally grouped with RVA genotype G2P.

\subsection{Phylogenetic studies}

In order to characterize MCPyV, the PCR amplicons were sequenced and phylogenetically analyzed along with reference sequences for the human polyomaviruses. The sequences clearly grouped with the Merkel cell cluster, with high bootstrap support (Fig. 2a). Further analysis of the MC cluster showed that the sequences reported in this work are divergent from previously reported sequences. While BCN 4 was the most divergent sequence, the sequences from Río de Janeiro formed a cluster (with low bootstrap support) with viral genomes from clinical specimens from the United States and Japan (Fig. 2b).

\subsection{Statistical studies}

The results show that there is no statistically significant difference between the results of viral recoveries obtained by the two laboratories in the intra- or inter-laboratory assays. In the intra-laboratory assay, (one-way ANOVA) the P-values obtained were 0.895 in Barcelona (HAdV, NoV and JCPyV) and 0.118 in Rio de Janeiro (HAdV, NoV and RV), whereas in the inter-laboratory assay (two-way ANOVA) the P-values for HAdV and NoV II (viruses analyzed in both laboratories) were 0.479 and 0.692 , respectively. No statistically significant differences were observed due to the day of the analysis ( $P$-value $>0.05$ ). The data were normally distributed (Shapiro-Wilks test, $P$-value $>0.05$ ) and homoscedastic (Bartlett's test, $P$-value $>0.05)$.

\section{Discussion}

The presence of human viruses in rivers is due to contamination from urban sewage and the stability of the viruses in response to environmental conditions. Here, the occurrence of new and emerging viruses (MCPyV, KIPyV, WUPyV, KV and ASFLV), gastroenteritis-related viruses (NoV GGII and RV) and 
A

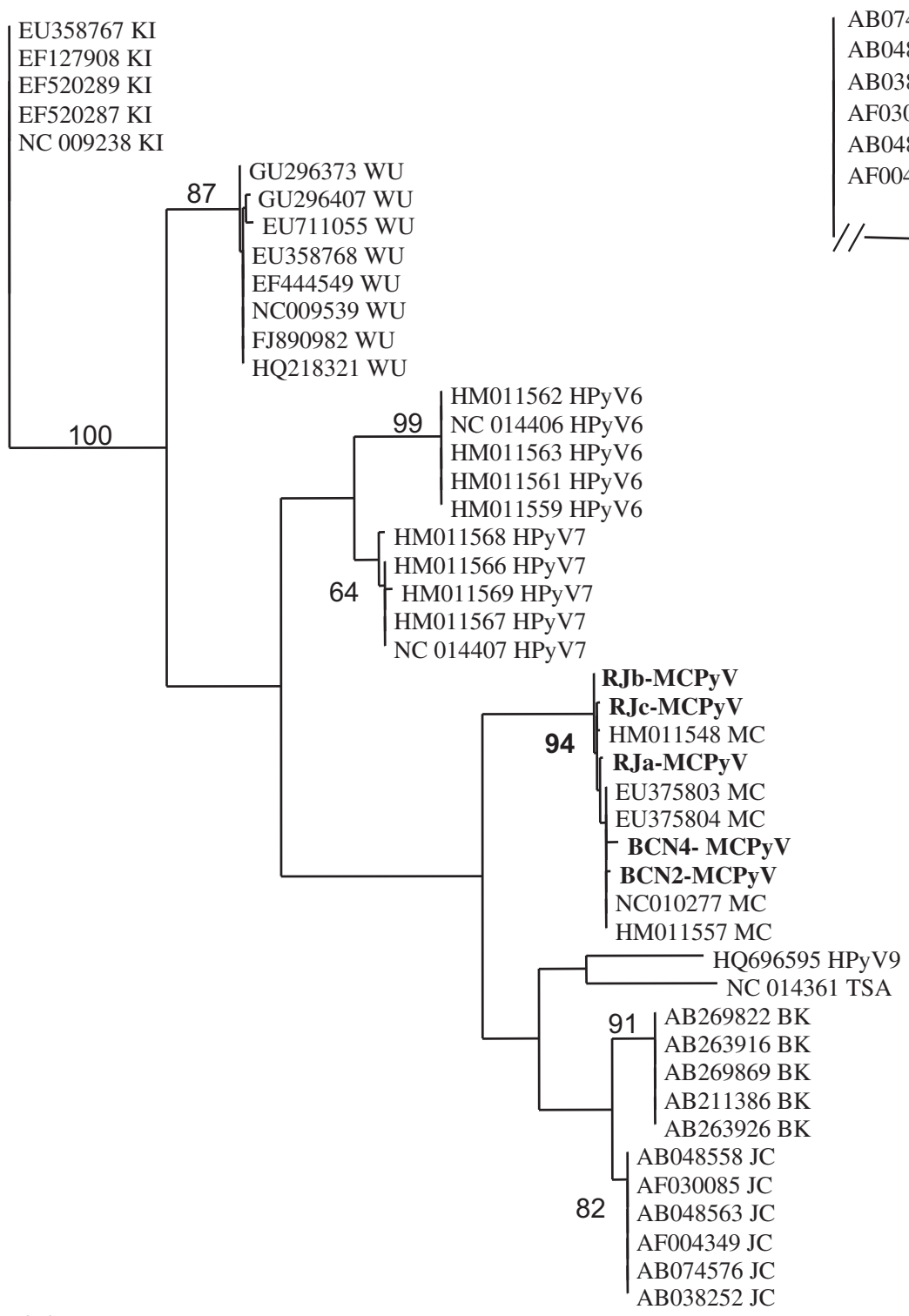

$\underline{01}$
B

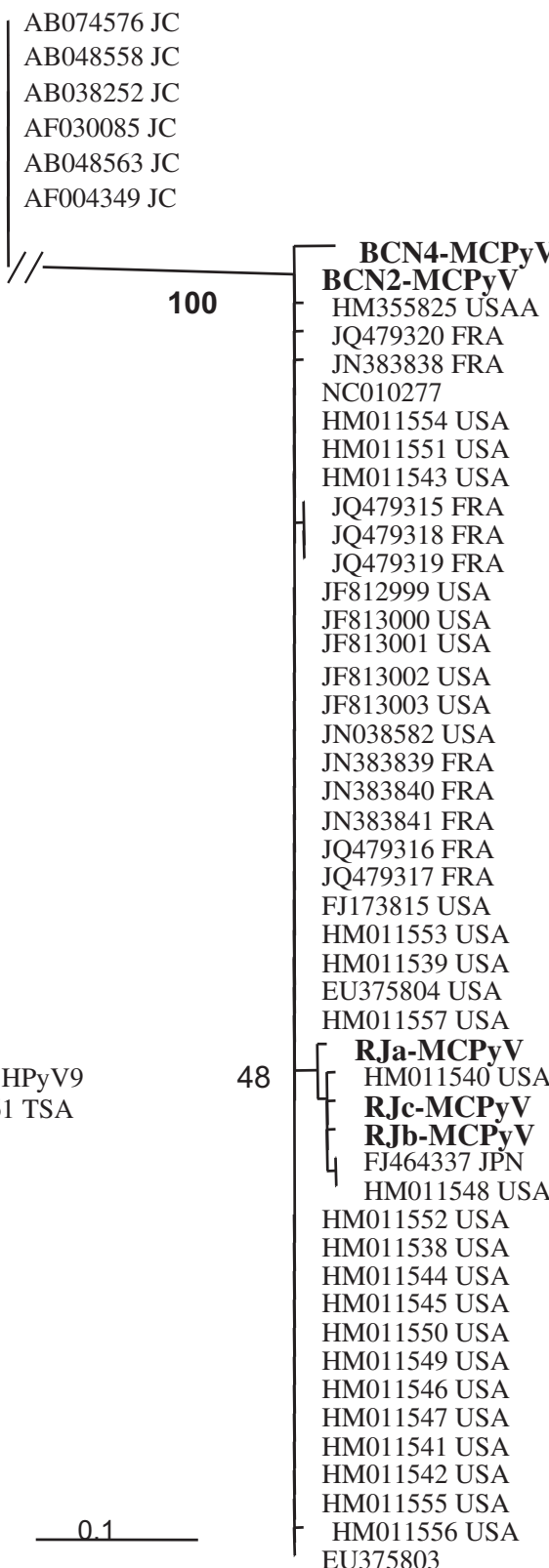

Fig. 2 - Maximum likelihood phylogenetic trees constructed at the VP2/VP3-VP1 junction of viral genomes from distinct human polyomaviruses (A) and MCPyVs (B) Sequences reported in this work are shown in bold letters. Sequences from GenBank are indicated by their accession numbers. Bootstrap values are given for the relevant groups. JCPyV was used as the outgroup in B. USA: United States; FRA: France; JPN: Japan; BCN: Barcelona, Spain; RJ: Río de Janeiro, Brazil.

viral indicators (HAdV and JCPyV) were studied in Barcelona and Rio de Janeiro, two different geographical contexts. Six samples per laboratory were analyzed during the month of March. The field samples analyzed represent specific information showing the level of viral contamination in the same period in two very different geographical areas, however, they may not accurately reflect the viral contamination in other periods of the year.

RT-nPCR and nPCR assays were designed to detect KV and ASFLV, by applying a set of specific primers for each virus.
Although the samples of river water from Barcelona tested negative for these viruses in the present study, previous tests on sewage from Barcelona have confirmed the presence of $\mathrm{KV}$ and ASFLV by conventional PCR and deep-sequencing, respectively (Holtz at al., 2009; Loh at al., 2009). The sporadic presence of KV and ASFLV in river water was confirmed by the tests conducted in Rio de Janeiro, where 2/6 and 1/6 positive results were obtained for $\mathrm{KV}$ and ASFLV, respectively. This data represents the first report of the presence of these viruses in river water. 
Of the new polyomaviruses studied here, only MCPyV was detected in Barcelona (3/6) and Rio de Janeiro (3/6), suggesting that this virus is stable in both sets of environmental conditions, probably similar to other human polyomaviruses such as BK and JCPyV. Interestingly, recent results describe MCPyV as an important member of the skin microbiota and so this virus could be shed from healthy humans via the skin (Wieland et al., 2009; Schowalter et al., 2010; Moens et al., 2011; Foulongne et al., 2012). The data described above strongly suggest that an important transmission route for MCPyV may be via water. Bofill-Mas et al. (2010a,b) reported a prevalence of $29 \%(2 / 7)$ for MCPyV in river water, and a much higher prevalence in urban sewage $89 \%(8 / 9)$. The positive detection of MCPyV in Rio de Janeiro represents the first data on the presence of this virus in Brazil. The identity of the MCPyV sequences was confirmed by the phylogenetic analysis. The high divergence of the sequences reported in this work, compared with the viral genomes for which full-length sequences are available in GenBank, could reflect the diversity of sequences from distinct geographical locations, since most of the GenBank genomes come from the United States and France. However, it should also be considered that the sequences from the environmental samples could represent the consensus of multiple viral genomes that are co-circulating in the population and have been discharged into the environment. Despite the low bootstrap support, the clustering of the Brazilian sequences is noteworthy and deserves further study.

Norovirus GGII was the most prevalent genogroup detected in many studies, especially genotype II.4 (Barreira et al., 2010; Ferreira et al., 2010; Wyn-Jones et al., 2011; Victoria et al., 2010; Bull and White, 2011; Prado et al., 2011). Previous studies showed a prevalence of $96.3 \%$ (104/108) for NoV GGII.4 in stool samples from patients with gastroenteritis in Río de Janeiro (Ferreira et al., 2010), while in a European study, a total of 1410 samples of water at popular recreational locatins (rivers and seawater) were positive for NoV: $6.2 \%$ for GGII and 3.5\% for GGI (Wyn-Jones et al., 2011). Based on these data, detection of NoV was only focused on GGII in the present study. The qPCR results showed a greater prevalence of NoV GGII in Barcelona $83 \%(5 / 6)$ than in Rio de Janeiro 33\% (2/6), this is probably related to the seasonal epidemiology of these viruses, with higher numbers during periods of lower temperatures. In the current study, the temperature in Barcelona at the time of sample collection was lower than in Rio de Janeiro, both in March 2009. The samples from Rio de Janeiro were not sequenced, however, selected samples from Barcelona (4/5) were sequenced and three samples were identified as NoV GGII.4, which is, as described above, the predominant genotype detected in many studies. One river water sample presented the emerging novel NoV GGII.12 (Vega and Vinjé, 2011). Rotaviruses was quantified and detected in 67\% (4/6) of the samples from Rio de Janeiro. The qPCR assays used do not discriminate between pathogenic and vaccine derived strains, however, the strains detected should be considered as pathogenic viruses since previous studies (Fumian et al., 2011) have shown that vaccine strains are not detected in urban wastewater from Rio de Janeiro.

The standard fecal indicators, E. coli and enterococci, are used to monitor fecal pollution in accord with public health regulations related to the quality of river water, groundwater and seawater (WHO, 2003; USEPA, 2004, 2006/160/EC). Nevertheless, the occurrence of bacterial indicators does not necessarily correlated with the presence of viral pathogens, which are more stable than bacteria in the environment (de Roda Husman et al., 2009), and does not provide information on the potential origin of the contamination. Some studies have reported substantial levels of enteric viruses in water that complies with regulations regarding the levels of bacterial fecal indicators (Brownell et al., 2007; Colford et al., 2007; Calgua et al., 2008; Wyn-Jones et al., 2011). To overcome this lack of correlation, several studies have proposed the use of HAdV and JCPyV as human fecal indicators (Pina et al., 1998; Bofill-Mas et al., 2000; Albinana-Gimenez et al., 2006; McQuaig et al., 2006; Miagostovich et al., 2008; McQuaig et al., 2009; Wyn-Jones et al., 2011). In the present study, 100\% (12/12) of the samples were positive for both viral these proposed indicators, HAdV and JCPyV, and in concentrations similar to those found in previous studies (Bofill-Mas et al., 2000; Albinana-Gimenez et al., 2006; McQuaig et al., 2006; Miagostovich et al., 2008; , McQuaig et al., 2009; Wyn-Jones et al., 2011). Although the number of samples is not high, these data support the stable distribution of both viruses in different geographical areas and the fact that their presence might be an accurate indication of human fecal contamination, and therefore also indicates the potential presence of other pathogenic viruses, such as the viruses detected in the present study.

The SM-flocculation procedure is based on the adsorption of the viruses to the flocs of skimmed milk. This concentration procedure was previously developed to concentrate viruses from seawater (Calgua et al., 2008). Fresh water and seawater differ in conductivity; fresh water having a conductivity of 40-2000 $\mu \mathrm{S} / \mathrm{m}$ and seawater having a conductivity of $4500-5000 \mu \mathrm{S} / \mathrm{m}$, which may affect adsorption of viral particles to flocs. Using a pre-flocculated skimmed milk solution, and artificial seawater either undiluted or in serial 10-fold dilutions, the effect of conductivity on the flocs and therefore viral recovery was assessed (data not shown). Based on the results, any water sample with levels of conductivity $\leq 1.5 \mathrm{mS}$ / $\mathrm{cm}$ should be conditioned by adding e.g. artificial sea salt (Sigma, Aldrich Chemie GMBH, Steinheim, Germany), to reach conductivity values $\geq 1.5 \mathrm{mS} / \mathrm{cm}$, prior to concentrating the viruses using the skimmed-milk flocculation procedure. During validation assays, to avoid underestimation of viral recovery caused by the specific composition of the concentrates from the water matrices (samples), viral recovery was estimated using as a reference, data on viruses quantified in concentrated water matrices following direct spiking of the viruses into the concentrate, similar to the procedure described by Lambertini et al. (2008). The endogenous virus strains of those used in the recovery assays (HAdV 2, JCPyV, NoV GGII and RV) were subtracted from the values of the viruses recovered in the recovery assays, the concentration of endogenous viruses were $10^{2}-10^{4} \mathrm{GC} / \mathrm{L}$ (data non show), low values in comparison with the spiked viruses. Validation assays were performed with the water matrices analyzed in the study and no inhibition problems were observed in the 10-fold diluted samples. Non-template and inhibition controls were included in each run. The inhibition controls were extra aliquots of the nucleic acids extracted from one sample with 
spiked standard DNA. Nucleic acid extractions of all samples were analyzed undiluted and 10-fold diluted and although low levels of inhibition were observed in some assays with undiluted samples, robust results were obtained in the 1:10 dilution. Intra- and inter-laboratory assays showed about $50 \%$ viral recovery for the viruses tested, values similar to the recoveries obtained by the method based on organic flocculation of skimmed milk for HAdV in seawater reported by Calgua et al. (2008). Available data of viral recovery values of different methods described in the literature may be difficult to compare. Concentration and quantification protocols (infectivity cell culture assays or qPCR), volume and type of water matrix used in the study have a strong influence on final results. Katayama et al. (2002), reported a concentration method (electronegative cellulose membrane and elution with $\mathrm{NaOH})$, for seawater based on two-step procedures, which showed a viral recovery of poliovirus about $82-95 \%$ obtained by plaque assays when they concentrate $50 \mathrm{~mL}-5 \mathrm{~mL}$ (viruses 10 -fold concentrated), and $62 \%$ when $1 \mathrm{~L}$ of sample was concentrate to $5 \mathrm{~mL}$. Wyn-Jones et al. (2011) described mean recoveries of HAdV using PFU and a protocol with glass wool filtration with elution using beef extract and flocculation of $57.1 \%$ (range $34.2-78 \%$ ). Recoveries using qPCR for the quantification of adenoviruses were described using $10 \mathrm{~L}$ samples of freshwater by Albinana-Gimenez et al. (2009) with a protocol based on ultrafiltration in the range between 3 and $6 \%$. Girones et al. (2010) showed a comparison of concentration methods for fresh and seawater for HAdV, where a low variability was observed with an one-step protocol for seawater, while high variability was observed with two step glass wool and electronegative-nitrocellulose membranes. The method for river water, similarly to the method for seawater (Calgua et al., 2008), does not require specialized equipment and would fulfill the conditions for a fitting method for routine public health laboratories: reproducibility, reliability, straightforwardness and cost-effectiveness.

In the present study, the inter-laboratory assays validated the use of the low-cost one-step procedure described above for the analysis of viruses in river water, detecting important viral pathogens such as RV, NoV and HAdV, as well as new and emerging viruses that are potentially transmitted through water, and confirming the global distribution of the proposed human viral indicators: HAdV and JCPyV.

\section{Conclusions}

- This study is the first description of the recently described viruses ASFLV and KV in river water and the first report of the presence of MCPyV in the environment in Brazil.

- The presence of MCPyV in rivers in Rio de Janeiro (3/6 samples) and Barcelona (3/6 samples) demonstrates that these viruses are abundantly excreted by the human population in different geographical areas.

- The RT-nPCR and nPCR developed here for the detection of $\mathrm{KV}$ and ASFLV, respectively, are specific molecular assays which could be applied in future clinical or environmental studies.

- The viral indicators HAdV and JCPyV are useful as markers of human fecal/urine contamination in water from diverse geographical areas since they show a high worldwide prevalence and stable concentrations.

- The results obtained in the inter- and intra-laboratory assays support the applicability of the one-step virus concentration procedure reported here as a routine protocol for virus quantification and for improving control of the microbiological quality of both seawater and fresh water.

- Gastroenteritis viruses such as NoV and RV, which are of great importance as pathogens in the regions studied, were quantified using the method described, and show highly variable concentrations in river samples in accordance with the reported epidemiology of these viruses.

\section{Acknowledgments}

This work was partially supported by the Spanish Government "Ministerio de Educación y Ciencia" (projects AGL200805275-C01/ALI and AGL2011-30461-C02-01). During the study Marta Rusiñol was a fellow of the Catalan research agency "AGAUR" (FI-DGR) in Spain. This work was also financially sponsored by the Brazilian National Council for Scientific and Technological Development (CNPq) and by the IOC/Fiocruz/ Ministry of Health, Brazil. The study was conducted under the scope of the activities of Fiocruz as a collaborating center of PAHO/WHO for Public and Environmental Health.

\section{R E F E R E N C E S}

Albinana-Gimenez, N., Clemente-Casares, P., Calgua, B., Huguet, J.M., Courtois, S., Girones, R., 2009. Comparison of methods for concentrating human adenoviruses, polyomavirus JC and noroviruses in source waters and drinking water using quantitative PCR. Journal of Virological Methods 158 (1-2), 104-109.

Albinana-Gimenez, N., Clemente-Casares, P., Bofill-Mas, S., Hundesa, A., Ribas, F., Girones, R., 2006. Distribution of human polyomaviruses, adenoviruses, and hepatitis $\mathrm{E}$ virus in the environment and in a drinking-water treatment plant. Environmental Science \& Technology 40 (23), 7416-7422.

Allander, T., Andreasson, K., Gupta, S., Bjerkner, A., Bogdanovic, G., Persson, M.A.A., Dalianis, T., Ramqvist, T., Andersson, B., 2007. Identification of a third human polyomavirus. The Journal of Virology 81, 4130-4136.

Allard, A., Albinsson, B., Wadell, G., 2001. Rapid typing of human adenoviruses by a general PCR combined with restriction endonuclease analysis. Journal of Clinical Microbiology 39 (2), 498-505.

Babakir-Mina, M., Ciccozzi, M., Campitelli, L., Aquaro, S., Lo Coco, A., Perno, C.F., Ciotti, M., 2009. Identification of the novel KI Polyomavirus in paranasal and lung tissues. Journal of Medical Virology 81, 558-561.

Barreira, D.M., Ferreira, M.S., Fumian, T.M., Checon, R., de Sadovsky, A.D., Leite, J.P., Miagostovich, M.P., Spano, L.C., 2010. Viral load and genotypes of noroviruses in symptomatic and asymptomatic children in Southeastern Brazil. Journal of Clinical Virology 47 (1), 60-64.

Berger, J.R., Major, E.O., 1999. Progressive multifocal leukoencephalopathy. Seminars in Neurology 19 (2), 1193-1200.

Bofill-Mas, S., Hundesa, A., Calgua, B., Rusiñol, M., de Motes, C.M., Girones, R., 2011. Cost-effective method for microbial source 
tracking using specific human and animal viruses. The Journal of Visualized Experiments 3 (58), e2820. http://dx.doi.org/ 10.3791/2820

Bofill-Mas, S., Pilar Clemente-Casares, P., Major, E.O., Curfman, B., Girones, R., 2003. Analysis of the excreted JC virus strains and their potential oral transmission. Journal of Neurovirology 9 (4), 498-507.

Bofill-Mas, S., Albinana-Gimenez, N., Clemente-Casares, P., Hundesa, A., Rodriguez-Manzano, J., Allard, A., Calvo, M., Girones, R., 2006. Quantification and stability of human adenoviruses and polyomavirus JCPyV in wastewater matrices. Applied and Environmental Microbiology 72 (12), 7894-7896.

Bofill-Mas, S., Calgua, B., Clemente-Casares, P., la Rosa, G., Iaconelli, M., Muscillo, M., Rutjes, S., de Roda Husman, A.M., Grunert, A., Gräber, I., Verani, M., Carducci, A., Calvo, M., WynJones, P., Girones, R., 2010a. Quantification of human adenoviruses in European recreational waters. Food and Environmental Virology 2 (2), 101-1009.

Bofill-Mas, S., Formiga-Cruz, M., Clemente-Casares, P., Calafell, F., Girones, R., 2001. Potential transmisión of human polyomaviruses through the gastrointestinal tract after exposure to virions or viral DNA. Journal of Virology 75, 10290-10299.

Bofill-Mas, S., Pina, S., Girones, R., 2000. Documenting the epidemiologic patterns of polyomaviruses in human populations by studying their presence in urban sewage. Applied and Environmental Microbiology 66 (1), 238-245.

Bofill-Mas, S., Rodriguez-Manzano, J., Calgua, B., Carratala, A., Girones, R., 2010b. Newly described human polyomaviruses Merkel cell, KI and WU are present in urban sewage and may represent potential environmental contaminants. Virology Journal 7 (1), 141.

Brownell, M.J., Harwood, V.J., Kurz, R.C., McQuaig, S.M., Lukasik, J., Scott, T.M., 2007. Confirmation of putative stormwater impact on water quality at a Florida beach by microbial source tracking methods and structure of indicator organism populations. Water Research 41 (16), 3747-3757.

Bull, R.A., White, P.A., 2011. Mechanisms of GII.4 norovirus evolution. Trends in Microbiology 19 (5), 233-240.

Calgua, B., Rodriguez-Manzano, J., Hundesa, A., Suñen, E., Calvo, M., Bofill-Mas, S., Girones, R., 2013. New methods for the concentration of viruses from urban sewage using quantitative PCR. Journal of Virological Methods 187 (2), 215-221.

Calgua, B., Mengewein, A., Grunert, A., Bofill-Mas, S., ClementeCasares, P., Hundesa, A., Wyn-Jones, A.P., López-Pila, J.M., Girones, R., 2008. Development and application of a one-step low cost procedure to concentrate viruses from seawater samples. Journal of Virological Methods 153 (2), 79-83.

Cantalupo, P.G., Calgua, B., Zhao, G., Hundesa, A., Wier, A.D., Katz, J.P., Grabe, M., Hendrix, R.W., Girones, R., Wang, D., Pipas, J.M., 2011. Raw sewage harbors diverse viral populations. MBio 2 (5), 1-11.

Colford, J.M., Wade, T.J., Schiff, K.C., Wright, C.C., Griffith, J.F., Sandhu, S.K., Burns, S., Sobsey, M., Lovelace, G., Weisberg, S.B., 2007. Water quality indicators and the risk of illness at beaches with nonpoint sources of fecal contamination. Epidemiology 18 (1), 27-35.

de Roda Husman, A.M., Lodder, W.J., Rutjes, S.A., Schijven, J.F., Teunis, P.F., 2009. Long-term inactivation study of three enteroviruses in artificial surface and groundwaters using PCR and cell culture. Applied and Environmental Microbiology 75 (4), 1050-1057.

Directive 2006/7/EC of the European Parliament and of the Council of 15 February 2006 concerning the management of bathing water quality and repealing Directive 76/160/EEC.

Feng, H., Shuda, M., Chang, Y., Moore, P.S., 2008. Clonal integration of a polyomavirus in human Merkel cell carcinoma. Science 319, 1096-1100.
Ferreira, M.S., Victoria, M., Carvalho-Costa, F.A., Vieira, C.B., Xavier, M.P., Fioretti, J.M., Andrade, J., Volotão, E.M., Rocha, M., Leite, J.P., Miagostovich, M.P., 2010. Surveillance of norovirus infections in the state of Rio De Janeiro, Brazil 2005-2008. Journal of Medical Virology 82 (8), 1442-1448.

Finkbeiner, S.R., Allred, A.F., Tarr, P.I., Klein, E.J., Kirkwood, C.D., Wang, D., 2008. Metagenomic analysis of human diarrhea: viral detection and discovery. Plos Pathogens 4 (2), e1000011.

Fong, T.T., Lipp, E.K., 2005. Enteric viruses of humans and animals in aquatic environments: health risks, detection and potential water quality assessment tools. Microbiology and Molecular Biology Reviews 69 (2), 357-371.

Foulongne, V., Sauvage, V., Hebert, C., Dereure, O., Cheval, J., Gouilh, M.A., Pariente, K., Segondy, M., Burguière, A., Manuguerra, J.C., Caro, V., Eloit, M., 2012. Human skin microbiota: high diversity of DNA viruses identified on the human skin by high throughput sequencing. PLoS One 7 (6), e38499.

Foulongne, V., Kluger, N., Dereure, O., Brieu, N., Guillot, B., Segondy, M., 2008. Merkel cell polyomavirus and Merkel cell carcinoma, France. Emerging Infectious Diseases 14 (9), 1491-1493.

Frisque, R.J., Bream, G.L., Cannella, M.T., 1984. Human polyomavirus JC virus genome. Journal of Virology 51 (2), 458-469.

Fumian, T.M., Gagliardi Leite, J.P., Rose, T.L., Prado, T., Miagostovich, M.P., 2011. One year environmental surveillance of rotavirus specie A (RVA) genotypes in circulation after the introduction of the Rotarix ${ }^{\circledR}$ vaccine in Rio de Janeiro, Brazil. Water Research 45, 5755-5763.

Fumian, T.M., Guimarães, F.R., Pereira Vaz, B.J., da Silva, M.T., Muylaert, F.F., Bofill-Mas, S., Girones, R., Leite, J.P., Miagostovich, M.P., 2010. Molecular detection, quantification and characterization of human polyomavirus JC from waste water in Rio De Janeiro, Brazil. Journal of Water and Health 8 (3), 438-445

Gallimore, C.I., Taylor, C., Gennery, A.R., Cant, A.J., Galloway, A., Iturriza-Gomara, M., Gray, J.J., 2006. Environmental monitoring for gastroenteric viruses in a pediatric primary immunodeficiency unit. Journal of Clinical Microbiology 44 (2), 395-399.

Gantzer, C., Maul, A., Audic, J.M., Schwartzbrod, L., 1998. Detection of infectious enteroviruses, enterovirus genomes, somatic coliphages and Bacteroides fragilis phages in treated wastewater. Applied and Environmental Microbiology 64, 4307-4312.

Gaynor, A.M., Nissen, M.D., Whiley, D.M., Mackay, I.M., Lambert, S.B., Wu, G., Brennan, D.C., Storch, G.A., Sloots, T.P., Wang, D., 2007. Identification of a novel polyomavirus from patients with acute respiratory tract infections. Plos Pathogens 3, 595-604.

Girones, R., Ferrús, M.A., Alonso, J.L., Rodriguez-Manzano, J., Calgua, B., Corrêa Ade, A., Hundesa, A., Carratala, A., BofillMas, S., 2010. Molecular detection of pathogens in water-the pros and cons of molecular techniques. Water Research 44 (15), 4325-4339.

Glass, R.I., Parashar, U.D., Estes, M.K., 2009. Norovirus gastroenteritis. The New England Journal of Medicine 361 (18), 1776-1785.

Greninger, A.L., Holtz, L., Kang, G., Ganem, D., Wang, D., De Risi, J.L., 2010. Serological evidence of human klassevirus infection. Clinical and Vaccine Immunology 17 (10), 1584-1588.

Greninger, A.L., Runckel, C., Chiu, C.Y., Haggerty, T., Parsonnet, J., Ganem, D., De Risi, J.L., 2009. The complete genome of klassevirus - a novel picornavirus in pediatric stool. Virology Journal 6, 82.

Guindon, S., Dufayard, J.F., Lefort, V., Anisimova, M., Hordijk, W., Gascuel, O., 2010. New algorithms and methods to estimate 
maximum-likelihood phylogenies: assessing the performance of PhyML 3.0. Systematic Biology 59 (3), 307-321.

Hall, T., 1999. BioEdit: a user-friendly biological sequence alignment editor and analysis program for Windows 95/98/NT. Nucleic Acid Symposium Series 41, 95-98.

Han, T.H., Kim, C.H., Chung, J.Y., Park, S.H., Hwang, E.S., 2010. Klassevirus infection in children, South Korea. Emerging Infectious Diseases 16 (10), 1623-1625.

Haramoto, E., Katayama, H., Ohgaki, S., 2004. Detection of noroviruses in tap water in Japan by means of a new method for concentrating enteric viruses in large volumes of freshwater. Applied and Environmental Microbiology 70, 2154-2160.

Hernroth, B.E., Conden-Hansson, A.C., Rehnstam-Holm, A.S., Girones, R., Allard, A.K., 2002. Environmental factors influencing human viral pathogens and their potential indicator organisms in the blue mussel, Mytilus edulis: the first Scandinavian report. Applied and Environmental Microbiology 68 (9), 4523-4533.

Holtz, L.R., Finkbeiner, S.R., Zhao, G., Kirkwood, C.D., Girones, R., Pipas, J.M., Wang, D., 2009. Klassevirus 1, a previously undescribed member of the family Picornaviridae, is globally widespread. Virology Journal 6, 86.

ISO 19458, 2006. Water Quality-Sampling for Microbiological Analysis. Guidance on Planning Water Sampling Regimes, on Sampling Procedures for Microbiological Analysis and on Transport, Handling and Storage of Samples until Analysis Begins.

Iturriza Gómara, M., Wong, C., Blome, S., Desselberger, U., Gray, J., 2002. Molecular characterization of VP6 genes of human rotavirus isolates: correlation of genogroups with subgroups and evidence of independent segregation. Journal of Virology 76 (13), 6596-6601.

Jothikumar, N., Lowther, J.A., Henshilwood, K., Lees, D., Hill, V.R., Vinjé, J., 2006. Rapid and sensitive detection of noroviruses by using TaqMan-Based One-Step Reverse Transcription-PCR assays and application to naturally contaminated shellfish samples. Applied and Environmental Microbiology 71 (4), 1870-1875.

Katayama, H., Shimasaki, A., Ohgaki, S., 2002. Development of a virus concentration method and its application to detection of enterovirus and Norwalk virus from coastal seawater. Applied and Environmental Microbiology 68, 1033-1039.

Khan, M.A., Bass, D.M., 2010. Viral infections: new and emerging. Current Opinion in Gastroenterology 26 (1), 26-30.

Kitamura, T., Aso, Y., Kuniyoshi, N., Hara, K., Yogo, Y., 1990. High incidence of urinary JC virus excretion in nonimmunosuppressed older patients. Journal of Infectious Diseases 161, 1128-1133.

Koo, H.L., Ajami, N., Atmar, R.L., DuPont, H.L., 2010. Noroviruses: the leading cause of gastroenteritis worldwide. Discovery Medicine 10 (50), 61-70.

Koralnik, I.J., Boden, D., Mai, V.X., Lord, C.I., Letvin, N.L., 1999. JC virus DNA load in patients with and without progressive multifocal leukoencephalopathy. Neurology 52, 253-260.

Lambertini, E., Spencer, S.K., Bertz, P.D., Loge, F.J., Kieke, B.A., Borchardt, M.A., 2008. Concentration of enteroviruses, adenoviruses, and noroviruses from drinking water by use of glass wool filters. Applied and Environmental Microbiology 74 (10), 2990-2996.

Lodder, W.J., van den Berg, H., Rutjes, S.A., de Roda Husman, A.M., 2010. Presence of enteric viruses in source waters for drinking water production in the Netherlands. Applied and Environmental Microbiology 76 (17), 5965-5971.

Loh, J., Zhao, G., Presti, R.M., Holtz, L.R., Finkbeiner, S.R., Droit, L., Villasana, Z., Todd, C., Pipas, J.M., Calgua, B., Girones, R., Wang, D., Virgin, H.W., 2009. Detection of novel sequences related to african Swine Fever virus in human serum and sewage. The Journal of Virology 83 (24), 13019-13025.

Löytynoja, A., Goldman, N., 2005 26. An algorithm for progressive multiple alignment of sequences with insertions. Proceedings of the National Academy of Sciences of the United States of America 102 (30), 10557-10562.

McQuaig, S.M., Scott, T.M., Harwood, V.J., Farrah, S.R., Lukasik, J.O., 2006. Detection of human-drived fecal pollution in environmental waters by use of a PCR-based human polyomavirus assay. Applied and Environmental Microbiology 72 (12), 7567-7574.

McQuaig, S.M., Scott, T.M., Lukasik, J.O., Paul, J.H., Harwood, V.J., 2009. Quantification of human polyomaviruses JC Virus and BK Virus by TaqMan quantitative PCR and comparison to other water quality indicators in water and fecal samples. Applied and Environmental Microbiology 75 (11), 3379-3388.

Miagostovich, M.P., Ferreira, F.F., Guimarães, F.R., Fumian, T.M., Diniz-Mendes, L., Luz, S.L., Silva, L.A., Leite, J.P., 2008. Molecular detection and characterization of gastroenteritis viruses occurring naturally in the stream waters of Manaus, central Amazonia, Brazil. Applied and Environmental Microbiology 74 (2), 375-382.

Moens, U., Ludvigsen, M., Van Ghelue, M., 2011. Human Polyomaviruses in Skin Diseases. Pathology Research International, 123491.

Pal, A., Sirota, L., Maudru, T., Peden, K., Lewis, A.M., 2006. Realtime PCR assays for the detection of virus-specific DNA in simples with mixed populations of polyomaviruses. Journal of Virological Methods 135 (1), 32-42.

Pallin, R., Wyn-Jones, A.P., Place, B.M., Lightfoot, N.F., 1997. The detection of enteroviruses in large volume concentrates of recreational waters by the polymerase chain reaction. Journal of Virological Methods 67, 57-67.

Parashar, U.D., Burton, A., Lanata, C., Boschi-Pinto, C., Shibuya, K., Steele, D., Birmingham, M., Glass, R.I., 2009. Global mortality associated with rotavirus disease among children in 2004. Journal of Infection Disease 1, 200.

Patel, M.M., Widdowson, M.A., Glass, R.I., Akazawa, K., Vinjé, J., Parashar, U.D., 2008. Systematic literature review of role of noroviruses in sporadic gastroenteritis. Emerging Infectious Diseases 14 (8), 1224-1231.

Pina, S., Puig, M., Lucena, F., Jofre, J., Girones, R., 1998. Viral pollution in the environment and shellfish: human adenovirus detection by PCR as an index of human viruses. Applied and Environmental. Microbiology 64, 3376-3382.

Posada, D., 2008. jModelTest: phylogenetic model averaging. Molecular Biology and Evolution 25, 1253-1256.

Prado, T., Silva, D.M., Guilayn, W.C., Rose, T.L., Gaspar, A.M., Miagostovich, M.P., 2011. Quantification and molecular characterization of enteric viruses detected in effluents from two hospital wastewater treatment plants. Water Research 45 (3), 1287-1297.

Puig, M., Jofre, J., Lucena, F., Allard, A., Wadell, G., Girones, R., 1994. Detection of adenoviruses and enteroviruses in polluted waters by nested PCR amplification. Applied and Environmental Microbiology 60, 2963-2970.

Pusch, D., Oh, D.Y., Wolf, S., Dumke, R., Schröter-Bobsin, U., Höhne, M., Röske, I., Schreier, E., 2005. Detection of enteric viruses and bacterial indicators in German environmental waters. Archives of Virology 150 (5), 929-947.

R: A Language and Environment for Statistical Computing, 2008. R Development Core Team, ISBN 3-900051-07-0. http://www.Rproject.org.

Rosario, K., Nilsson, C., Lim, Y.W., Ruan, Y., Breitbart, M., 2009. Metagenomic analysis of viruses in reclaimed water Environmental. Microbiology 11, 2806-2820.

Schael, I.P., Gonzalez, R., Salinas, B., 2009. Severity and age of rotavirus diarrhea, but not socioeconomic conditions, are 
associated with rotavirus seasonality in Venezuela. Journal of Medical Virology 81, 562-567.

Schowalter, R.M., Pastrana, D.V., Pumphrey, K.A., Moyer, A.L., Buck, C.B., 2010. Merkel cell polyomavirus and two previously unknown polyomaviruses are chronically shed from human skin. Cell Host \& Microbe 7 (6), 509-515.

Shan, T., Wang, C., Cui, L., Yu, Y., Delwart, E., Zhao, W., Zhu, C., Lan, D., Dai, X., Hua, X., 2010. Picornavirus salivirus/ klassevirus in children with diarrhea, China. Emerging Infectious Diseases 16 (8), 1303-1305.

Sobsey, M.D., Wallis, C., Henderson, M., Melnick, J.L., 1973. Concentration of enteroviruses from large volumes of water. Applied Microbiology 26 (4), 529-534.

USEPA, 2004. Water Quality Standards for Coastal and Great Lakes Recreation Waters, vol. 69. p. 220.

van den Berg, H., Lodder, W., van der Poel, W., Vennema, H., de Roda Husman, A.M., 2005. Genetic diversity of noroviruses in raw and treated sewage water. Research in Microbiology 156, 532-540.

Vega, E., Vinjé, J., 2011. Novel GII.12 norovirus strain, United States, 2009-2010. Emerging Infectious Diseases 17 (8), 1516-1518.

Vennema, H., de Bruin, E., Koopmans, M., 2002. Rational optimization of generic primers used for Norwalk-like virus detection by reverse transcriptase polymerase chain reaction. Journal of Clinical Virology 25 (2), 233-235.

Verzani, J., 2004. Using R for Introductory Statistics. Chapman \& Hall/CRC.

Victoria, M., Guimarães, F.R., Fumian, T.M., Ferreira, F.F., Vieira, C.B., Shubo, T., Leite, J.P., Miagostovich, M.P., 2010. One year monitoring of norovirus in a sewage treatment plant in Rio de Janeiro, Brazil. Journal of Water and Health 8 (1), 158-1565.
Vilaginès, P., Sarrette, B., Husson, G., Vilaginès, R., 1993. Glass wool for virus concentration at ambient water $\mathrm{pH}$ level. Water Science and Technology 27, 299-306.

Weber, T., Trebst, C., Frye, S., Cinque, P., Vago, L., Sindic, C.J., Schulz-Schaeffer, W.J., Kretzschmar, H.A., Enzensberger, W., Hunsmann, G., Luke, W., 1997. Analysis of the systemic and intrathecal humoral immune response in progressive multifocal leukoencephalopathy. Journal of Infection Diseases 176, 250-254.

WHO, 2003. Guidelines for Safe Recreational Water Environments. In: Coastal and Freshwaters, vol. 1. World Health Organisation, Geneva, 219.

Wieland, U., Mauch, C., Kreuter, A., Krieg, T., Pfister, H., 2009. Merkel cell polyomavirus DNA in persons without merkel cell carcinoma. Emerging Infectious Diseases 15 (9), 1496-1498.

Wyn-Jones, A.P., Carducci, A., Cook, N., D'Agostino, M., Divizia, M., Fleischer, J., Gantzer, C., Gawler, A., Girones, R., Höller, C., de Roda Husman, A.M., Kay, D., Kozyra, I., LópezPila, J., Muscillo, M., Nascimento, M.S., Papageorgiou, G., Rutjes, S., Sellwood, J., Szewzyk, R., Wyer, M., 2011. Surveillance of adenoviruses and noroviruses in European recreational waters. Water Research 45 (3), 1025-1038.

Yousry, T.A., Major, E.O., Ryschkewitsch, C., Fahle, G., Fischer, S., Hou, J., Curfman, B., Miszkiel, K., Mueller-Lenke, N., Sanchez, E., Barkhof, F., Radue, E.W., Jager, H.R., Clifford, D.B., 2006. Evaluation of patients treated with natalizumab for progressive multifocal. The New England Journal of Medicine 354, 924-933.

Zeng, S.Q., Halkosalo, A., Salminen, M., Szakal, E.D., Puustinen, L., Vesikari, T., 2008. One-step quantitative RT-PCR for the detection of rotavirus in acute gastroenteritis. Journal of Virological Methods 153, 238-240. 